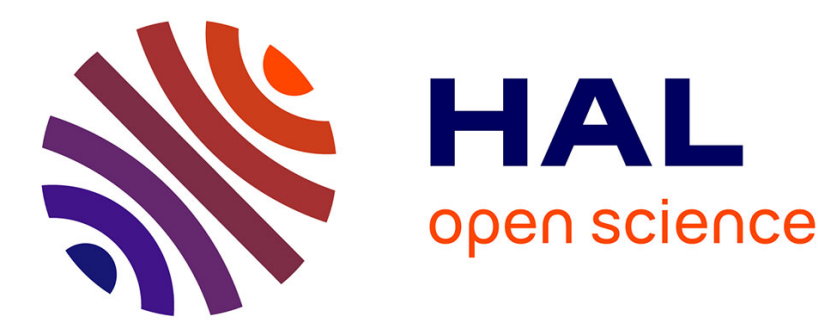

\title{
PERFORMANCE OF A HYBRID FUNGAL PATHOGEN ON PURE-SPECIES AND HYBRID HOST PLANTS
}

Amanda K Gibson, Guislaine Refrégier, Michael E Hood, Tatiana Giraud

\section{- To cite this version:}

Amanda K Gibson, Guislaine Refrégier, Michael E Hood, Tatiana Giraud. PERFORMANCE OF A HYBRID FUNGAL PATHOGEN ON PURE-SPECIES AND HYBRID HOST PLANTS. International Journal of Plant Sciences, 2014, 10.1086/676621 . hal-01302688

\section{HAL Id: hal-01302688 \\ https://hal.science/hal-01302688}

Submitted on 15 Apr 2016

HAL is a multi-disciplinary open access archive for the deposit and dissemination of scientific research documents, whether they are published or not. The documents may come from teaching and research institutions in France or abroad, or from public or private research centers.
L'archive ouverte pluridisciplinaire HAL, est destinée au dépôt et à la diffusion de documents scientifiques de niveau recherche, publiés ou non, émanant des établissements d'enseignement et de recherche français ou étrangers, des laboratoires publics ou privés. 
Int. J. Plant Sci. 175(6):724-730. 2014.

(C) 2014 by The University of Chicago. All rights reserved.

1058-5893/2014/17506-0008\$15.00 DOI: $10.1086 / 676621$

\title{
PERFORMANCE OF A HYBRID FUNGAL PATHOGEN ON PURE-SPECIES AND HYBRID HOST PLANTS
}

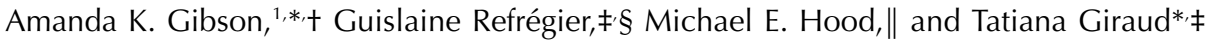 \\ *Laboratoire Ecologie, Systématique, et Evolution, Centre National de la Recherche Scientifique (CNRS), 91405 Orsay, France; tDepartment of \\ Biology, Indiana University, Bloomington, Indiana 47405, USA; łLaboratoire Ecologie, Systématique, et Evolution, Université Paris Sud, 91405 \\ Orsay, France; §Institut de Génétique et Microbiologie, CNRS, and Université Paris Sud, 91405 Orsay, France; and \\ ||Department of Biology, Amherst College, Amherst, Massachusetts 01002, USA
}

Editor: Christina Caruso

Premise of research. Recent hybridization events in fungi have produced emerging pathogens characterized by novel host specificities, increased infectivity, and/or elevated severity. We investigated the potential for host shifts and increased infectivity following hybridization of fungal pathogens in the genus Microbotryum, which causes anther-smut disease on caryophyllaceous hosts. Hybrids of the closely related species Microbotryum lychnidis-dioicae $(\mathrm{MvSl})$ and Microbotryum silenes-dioicae $(\mathrm{MvSd})$ are viable and fertile. Although historical genetic exchange between $\mathrm{MvSl}$ and $\mathrm{MvSd}$ is rare, there is evidence of recent hybridization of these fungal species, as well as of their plant hosts, Silene latifolia and Silene dioica.

Methodology. We examined the fitness of hybrid pathogens and hosts by using $\mathrm{F}_{1}$ hybrids of $\mathrm{MvSl} \times$ MvSd to inoculate $S$. latifolia $\times S$. dioica hybrids. Experimental inoculations of $S$. latifolia and hybrid hosts with pure-species and hybrid pathogens allowed assessment of the likelihood of hybrid emergence on a novel host (the hybrid plant) and of increased infectiousness of the hybrid pathogen on the pure-species host.

Pivotal results. We found no evidence for pathogen hybrid inferiority, arguing against interspecific incompatibilities at small genetic distances. Instead, we found that hybrid pathogens are more infectious on pure-species hosts, while pure-species pathogens are more infectious on hybrid hosts, indicating an interaction of host and parasite genotypes.

Conclusions. This finding argues against emergence of hybrid pathogens on a novel hybrid host. However, our study suggests that hybridization of pathogens and hosts in natural populations may lead to elevated disease prevalence overall, thus furthering the impact of anther-smut disease in these Silene species.

Keywords: hybridization, genotype-by-genotype interactions, virulence, aggressiveness, infectivity, ecologically based inviability.

Online enhancements: appendix tables.

\section{Introduction}

The merging of genomes through interspecific hybridization can generate phenotypes capable of exploiting new ecological and evolutionary opportunities (Lewontin and Birch 1966; Rieseberg 2003; Gross and Rieseberg 2005; Mallet 2007). There is great concern, therefore, that hybridization influences the emergence of novel infectious diseases, with hybrid pathogens able to colonize new hosts or to be more infectious and severe than their pure-species parents (Brasier 2001; Arnold 2004; Farrer et al. 2011). Indeed, the reassortment of influenza A lineages poses one of the greatest threats to human health today (Brown et al. 1998; Holmes et al. 2005; Nelson et al. 2008; Lam et al. 2013). Fungal and fungal-like diseases ex-

\footnotetext{
${ }^{1}$ Author for correspondence; e-mail: amakgibs@indiana.edu.
}

Manuscript received December 2013; revised manuscript received March 2014; electronically published May 27, 2014. emplify this phenomenon: in the past $15 \mathrm{yr}$, emerging fungal and oomycete pathogens have been repeatedly linked to hybridization events. For example, the global expansion of Dutch elm disease and its destructiveness in the second half of the twentieth century are attributed to genetic exchange between two Ophiostoma species, the causative agents of this wilt disease (Brasier et al. 1998; Brasier 2001). This case and many others (Brasier et al. 1999; Newcombe et al. 2000; Brasier 2001; Kamoun 2001; Olson and Stenlid 2002; Giraud et al. 2008; Stukenbrock and McDonald 2008; Farrer et al. 2011; Stukenbrock et al. 2012) attest to the importance of hybridization and recombination in shaping the distribution of infectious disease, as well as the infectiousness and harm inflicted by pathogens.

The fungal genus Microbotryum (Basidiomycota: Microbotryales) provides an interesting system in which to investigate hybrid pathogens. It has a documented history of hybridization, potentially coupled with shifts to novel hosts 
(Refrégier et al. 2008; Devier et al. 2010), and indications of an ongoing increase in hybridization between certain species (Gladieux et al. 2011). Many Microbotryum pathogens infect plants in the Caryophyllaceae family, causing the sterilizing disease anther-smut, with different Microbotryum species specialized to infect different host species (Kemler et al. 2006; Le Gac et al. 2007a; Lutz et al. 2008; Denchev et al. 2009). The primary symptom of anther-smut disease is the replacement of host pollen by dark fungal spores. Pollinators vector spores from the anthers of infected hosts to floral and vegetative surfaces of healthy plants, where the diploid spores germinate, undergo meiosis, and conjugate to form dikaryotic hyphae (Schäfer et al. 2010). These hyphae invade host tissue and colonize meristems of the host, which is sterilized by pollen replacement and abortion of ovaries. There is clearly a genetic basis to variation in host resistance, both within (Alexander and Maltby 1990; Thrall and Jarosz 1994; Alexander and Antonovics 1995; Biere and Antonovics 1996; Carlsson-Granér 1997; Giles et al. 2006; Cafuir et al. 2007) and between (Antonovics et al. 2002; Le Gac et al. 2007b; Giraud and Gourbière 2012) closely related host species, as well as to variation between species of Microbotryum in their ability to cause disease (Antonovics et al. 2002; Le Gac et al. 2007b; Giraud and Gourbière 2012).

Hybrids of closely related Microbotryum species infecting closely related plants are viable and fertile (Le Gac et al. 2007b; Sloan et al. 2008; de Vienne et al. 2009), as seen for Microbotryum lychnidis-dioicae (MvSl) and Microbotryum silenesdioicae $(\mathrm{MvSd})$, parasitizing Silene latifolia and Silene dioica, respectively. In natural populations, ample opportunity seems to exist for hybridization of $\mathrm{MvSl}$ and $\mathrm{MvSd}$ : sympatry of the host and pathogen species is common, and pollinators that disperse the fungal spores from smutted anthers are frequently generalist (Goulson and Jerrim 1997; Van Putten et al. 2005, 2007; Minder et al. 2007; Karrenberg and Favre 2008). Though evidence of hybridization is rare (Refrégier et al. 2010; Gladieux et al. 2011), gene flow appears to be increasing, possibly due to secondary contact following a period of allopatry (Gladieux et al. 2011).

Hybrids between the host plants S. latifolia and $S$. dioica are also fertile, and the two species are frequently sympatric or parapatric (Baker 1948). They are, however, clearly delineated as distinct species by ecological habit, morphology, and molecular data (Delmotte et al. 1999; Karrenberg and Favre 2008; Minder and Widmer 2008; Goulson 2009). Rare hybrids do occur in nature (Minder et al. 2007; Karrenberg et al. 2008), especially at contact zones between plant species (Goulson 2009). Human disturbances (e.g., farming, roadsides) are hypothesized to create habitat suitable for both plant species (Karrenberg and Favre 2008; Goulson 2009). Contact between S. latifolia and S. dioica can create opportunities for both host hybridization and pathogen hybridization, via pollinator movement of pollen and fungal spores, respectively, between host species. The dynamics of such multihost, multipathogen interactions between closely related species are poorly understood, and studies are required to illuminate the dynamics expected in cases of secondary contact.

Accordingly, we experimentally model this natural scenario in which contact between closely related hosts promotes formation of pathogen hybrids, which may then interact with pure-species and hybrid hosts. Specifically, we compare fitness, measured as the rate of disease, of hybrid and pure-species pathogens on hybrid and pure-species plants. We perform reciprocal artificial inoculations using lab-bred $F_{1}$ hybrids between S. latifolia and S. dioica and their pathogens, MvSl and MvSd. While the general alarm over the emergence of hybrid pathogens suggests the hypothesis that interspecific crosses will result in increased disease, there are several possible outcomes. Hybrid pathogens might have consistently lower or higher fitness, due to hybrid incompatibilities or vigor, respectively. Relatedly, hybrid hosts could be more susceptible or more resistant regardless of pathogen genotype. In contrast, more complex patterns might emerge based on the interaction of host and pathogen alleles. For example, hybrid hosts could constitute an intermediate habitat most suitable for hybrid pathogens. We thus addressed the following questions: (1) Do Microbotryum hybrids show altered ability to cause disease on all hosts, suggestive of either genetic incompatibilities or hybrid advantage? (2) Is the ability to cause disease alternately mediated by an interaction of pathogen and host genotypes, such that pure-species and hybrid pathogens differ in disease rates on pure-species and hybrid hosts? If hybrid pathogens cause more disease on hybrid hosts, then a hybrid pathogen has greater potential to establish on emerging hybrid hosts. If hybrid pathogens instead cause more disease on pure-species hosts, pathogen hybridization could elevate the disease burden of pure-species-host populations.

\section{Methods}

\section{Preparation of Fungal Strains}

All Microbotryum strains used as inocula are detailed in table A1 (tables A1-A4 available online). Three to four fieldcollected samples were chosen to represent each of two fungal species: MvSl, collected from natural populations of the host Silene latifolia and $\mathrm{MvSd}$, collected from the host Silene dioica. There is no known variation in the propensity of different strains of MvSl and MvSd to hybridize (Refrégier et al. 2010).

Inoculum preparation was conducted as described in Gibson et al. (2012). Briefly, for each Microbotryum sample, a single anther was extracted from preserved diseased flowers and serially diluted prior to growth on GMB2 medium (Thomas et al. 2003). Following serial dilution and further growth, colonies derived by mitotic replication of a single haploid sporidium were isolated and tested for mating type under a conjugation assay (Le Gac et al. 2007b). As often occurs, some $\mathrm{MvSl}$ isolates showed mating-type bias (Oudemans et al. 1998; Thomas et al. 2003): only the $a_{1}$ mating type was available for the $\mathrm{MvSl}$ strain 703.2, so the $\mathrm{a}_{2}$ mating type from an additional strain, MvS1 729.2, was included (table A1).

\section{Preparation of Host Populations}

Seeds of $S$. latifolia and $S$. dioica were derived from populations in Orsay and Brittany, France, respectively (table A2). Seeds of $F_{1}$ hybrids from these host species were derived from artificial greenhouse crosses conducted in Orsay by reciprocally pollinating individuals of the two plant species. $F_{1}$ seeds from $S$. latifolia and $S$. dioica mothers were then pooled. Purespecies host plants of $S$. dioica were initially included in this 

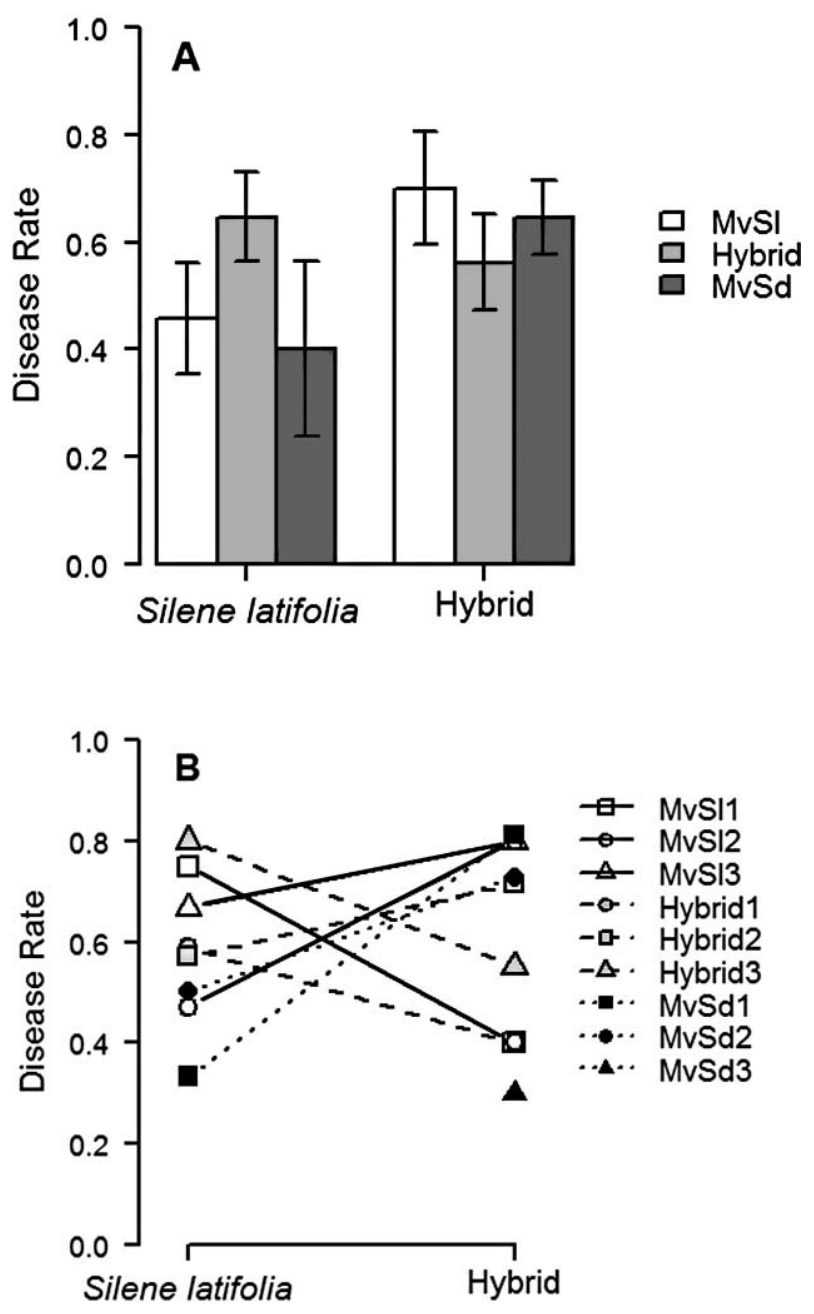

Fig. 1 Disease rate by host and pathogen combination. $A$, The proportion of inoculated plants that became infected is shown for Silene latifolia and the hybrid host inoculated with Microbotryum lychnidis-dioicae (MvSl), Microbotryum silenes-dioicae (MvSd), and the hybrid pathogen $(\mathrm{MvSl} \times \mathrm{MvSd})$, averaged across all strains. Error bars show standard error of the proportion. $B$, The proportion of inoculated plants that became infected is shown according to the pathogen strain used. Strains included three strains for each of MvSl, MvSd, and the hybrid pathogen. Hybrid strains are numbered according to the MvSl and MvSd strains crossed to generate the hybrid (e.g., hybrid 1: MvSl1 $\times$ MvSd1). None of the S. latifolia plants that were inoculated with MvSd3 flowered, so disease rate could not be assessed for this treatment group.

experiment as well. However, very few S. dioica plants successfully flowered under greenhouse conditions, so this host was excluded from the following analyses. Seed sterilization and germination in preparation for inoculation were conducted as described in Gibson et al. (2012).

\section{Inoculation and Treatment Design}

The inoculum was prepared by combining equivalent amounts of $a_{1}$ and $a_{2}$ sporidial cultures in $400 \mu \mathrm{L}$ of water. Seedlings were treated with $4 \mu \mathrm{L}$ of inoculum on first emer- gence of their cotyledons. Microbotryum crosses were either intraspecific, between haploid genotypes of $\mathrm{MvSl}$ or haploid genotypes of $\mathrm{MvSd}$, or interspecific, between haploid genotypes of $\mathrm{MvSl}$ and $\mathrm{MvSd}$. A total of six intraspecific crosses (three $\mathrm{MvSl}$ and three MvSd crosses) and three interspecific (hybrid) crosses were conducted. The particular combinations of sporidia for each cross are detailed in table A3. Each of these nine crosses was inoculated on both pure-species $S$. latifolia and $\mathrm{F}_{1}$ hybrid $S$. latifolia $\times S$. dioica host plant populations, resulting in 18 treatment groups. Twenty-five plants were inoculated per treatment group and maintained at $15^{\circ} \mathrm{C}$ for $2-4 \mathrm{~d}$ of incubation. All treatments are presented in detail in table A4.

\section{Data Collection and Genotyping}

Following incubation, seedlings were transplanted in a randomized fashion to soil in the greenhouse. Upon flowering, plants were visually assessed for symptoms of anther-smut disease. All flowering plants were removed from the flower beds as soon as the first flower appeared in order to avoid secondary contamination. The identity of healthy and diseased plants was noted. Disease rates were calculated as the percentages of flowering plants that were visibly infected within each treatment.

\section{Statistical Analysis}

To analyze the factors affecting the probability of infection, a logistic regression was performed with JMP 3 (SAS Institute, Cary, NC). For each inoculated plant, presence or absence of infection was treated as the response variable. Host (S. latifolia or hybrid), pathogen (MvSl, MvSd, or hybrid), and the interaction of host and pathogen were treated as predictor variables. An additional larger model was also performed in order to assess pathogen strain, nested within pathogen, as a predictor of disease rate.

\section{Results}

An average of $37.3 \%$ of plants $(N=168$ of 450$)$ flowered in the 18 treatment groups, ranging from $0 \%$ to $88 \%$ (table A4). Excluding all plants that failed to flower, artificial inoculations resulted in high disease rates $(\geq 40 \%)$ on Silene latifolia and hybrid plants for all inoculum treatments (fig. 1), allowing analysis of the explanatory variables. Host (S. latifolia or hybrid) and pathogen ( $\mathrm{MvSl}, \mathrm{MvSd}$, or hybrid) were not significant predictors of disease rate (table 1 ). This result addresses our first question: we conclude that there is no evi-

Table 1

Results of Logistic Regression for Disease Rate

\begin{tabular}{lrcc}
\hline Source & \multicolumn{1}{c}{$\chi^{2}$} & $\mathrm{df}$ & $P$ \\
\hline Host & .244 & 1 & .6213 \\
Pathogen & 1.053 & 2 & .5908 \\
Host $\times$ pathogen & 10.185 & 2 & .0061 \\
\hline
\end{tabular}

Note. Host (Silene latifolia, hybrid), pathogen (Microbotryum lychnidis-dioicae, Microbotryum silenes-dioicae, and hybrid), and the interaction of host and pathogen are examined as predictor variables (whole model: $P=0.0286, r^{2}=0.0394$ ). 
dence for either universal depression of hybrid fitness in the host or pathogen, consistent with hybrid inferiority, or universal elevation of hybrid fitness, consistent with hybrid superiority.

The interaction of host and pathogen type was a significant predictor of disease rate (table 1). This result addresses our second question: disease rate is mediated by an interaction of host and parasite genotype. Specifically, we found that hybrid pathogens performed worse on hybrid hosts and better on pure-species hosts relative to pure-species pathogens (fig. $1 A$ ). Disease rates of hybrid pathogens are higher on pure-species S. latifolia plants than on hybrid plants, while the disease rates of pure-species pathogens are higher on hybrid plants than on pure-species plants. We note that the variation of strains within a pathogen type is substantial (fig. 1B). A larger model including the effect of pathogen strain nested within pathogen nevertheless found the strain effect to be insignificant and the interaction of host and pathogen to be marginally significant in predicting disease rate (table 2 ).

\section{Discussion}

Our results show that hybrid pathogens between $\mathrm{MvSl}$ and $\mathrm{MvSd}$ do not have uniformly higher or lower fitness than their parents. Rather the relative fitness of hybrid pathogens is contingent on host genotype. Hybrid pathogens are more infectious on pure-species hosts than are pure-species pathogens, indicating a potential link between pathogen hybridization and increased virulence.

The insignificance of pathogen genotype as a predictor of disease rate overall indicates that hybrid pathogens are not uniformly less fit than their parents, as might be expected if genetic incompatibilities on hybrid viability were present (Dobzhansky 1936; Muller and Pontecorvo 1940; Muller 1942; Burke and Arnold 2001). This is consistent with previous work in Microbotryum. Although distantly related species show reduced viability and fertility (Le Gac et al. 2007b; Sloan et al. 2008; de Vienne et al. 2009), hybrids of closely related MvSl and MvSd are consistently viable and fertile (Le Gac et al. 2007b; de Vienne et al. 2009). Previous results on the postmating performance of backcrossed hybrids of $\mathrm{MvSl}$ and $\mathrm{MvSd}$ on pure-species host indicate that isolation results mainly from ecological incompatibility of hybrids: backcross progenies with a higher proportion of the pathogen genome native to the particular host environment were most fit (Büker et al. 2013). Even at greater genetic distances, Giraud and Gourbière (2012) found no evidence that negative interactions between loci in divergent lineages contribute to reproductive isolation of fungal species. They again support an ecological basis for hybrid inviability, in which the fitness of hybrid genotypes depends on their ability to cause disease on available hosts (Giraud et al. 2010).

The insignificance of pathogen genotype as a predictor of disease rate also signifies that there is no uniform fitness advantage of hybridization. Hybrid progenies may be predicted to have elevated fitness for multiple reasons, including heterosis and positive epistasis of newly combined loci (as reviewed in Burke and Arnold 2001). No fitness advantage of hybridization was apparent here, however. Importantly, this study examined the fitness of three unique $\mathrm{F}_{1}$ hybrids, derived from
Table 2

\begin{tabular}{lccc}
\multicolumn{4}{c}{$\begin{array}{c}\text { Results of Logistic Regression for Disease } \\
\text { Rate including Strain Effect }\end{array}$} \\
\hline Source & $\chi^{2}$ & $\mathrm{df}$ & $P$ \\
\hline Host & 1.268 & 1 & .2601 \\
Pathogen & 3.097 & 2 & .2126 \\
Strain [pathogen] & 8.141 & 6 & .2258 \\
Host $\times$ pathogen & 4.961 & 2 & .0837 \\
\hline
\end{tabular}

Note. Host (Silene latifolia, hybrid), pathogen (Microbotryum lychnidis-dioicae, Microbotryum silenes-dioicae, and hybrid), strain nested within pathogen $(1,2,3)$, and the interaction of host and pathogen are examined as predictor variables (whole model: $\left.P=0.3180, r^{2}=0.0561\right)$.

genetically divergent parents (Delmotte et al. 1999; Bucheli et al. 2001; Giraud 2004). We might then expect the fitness of hybrid genotypes to vary widely. If hybrid genotypes with elevated fitness arise because hybridization increases the variance of a trait (Arnold and Hodges 1995), then examining more hybrid genotypes might reveal a subset with elevated fitness. Variation in infectivity between strains was substantial but no higher between hybrid strains than between pure-species strains (fig. 1B). Nevertheless, with only three hybrid genotypes, we cannot exclude low sample size as an explanation for the failure to observe hybrid vigor.

While no uniform difference in hybrid- and pure-speciespathogen fitness was observed, the interaction of host and pathogen genotype was a significant predictor of disease rate. Thus, novel gene combinations may be fitter on certain hosts, indicating a role for genotype-by-genotype interactions in determining infection success (Carius et al. 2001; Laine 2004; Lively et al. 2004; Little et al. 2006; Salvaudon et al. 2007). This interaction effect in and of itself is an important result given that little is currently known regarding the genetics underlying the interaction between Silene and Microbotryum. The hybrid pathogen had a lower disease rate on the hybrid host and a higher disease rate on the pure-species host than did pure-species pathogens. The $\mathrm{F}_{1}$ hybrid pathogens combine infection loci from both MvSd and MvSl, which have coevolved with Silene dioica and Silene latifolia, respectively. The advantage of the hybrid pathogen on the pure-species host may arise from the combination of proteins actively involved in host infection (i.e., effectors) from both $\mathrm{MvSl}$ and $\mathrm{MvSd}$, with which the nonhost pure-species plants have not coevolved. In contrast, the hybrid host combines resistance loci of both $S$. latifolia and $S$. dioica, which have evolved to recognize $\mathrm{MvSl}$ or MvSd effectors, respectively. This combination of resistance loci from both parent hosts may put the hybrid pathogen at a disadvantage on the hybrid host. We were unable to obtain data from artificial inoculations of pure-species $S$. dioica hosts in this study, but Le Gac et al. (2007b) found that the disease rate of $\mathrm{MvSl} \times \mathrm{MvSd}$ hybrids on $S$. dioica was at least as high as that of MvSd on S. dioica. This is consistent with our finding that hybrid pathogens are successful on pure-species hosts, perhaps more so than are pure-species pathogens.

Our findings have important implications for natural populations undergoing secondary contact of closely related hosts and their pathogens. In mixtures of pure-species and hybrid hosts and pathogens, the hybrid host may negatively influence 
the potential for hybrid-mediated gene flow in the pathogen, as hybrid pathogens have low fitness in the presence of hybrid hosts. The pathogen may likewise negatively influence the potential for hybrid-mediated gene flow between host species as hybrid hosts have low fitness in the presence of pure-species pathogens. Our results thus suggest that increased disease susceptibility could be an additional ecological factor explaining the rarity of hybrids between S. dioica and S. latifolia (Goulson and Jerrim 1997; Fritz et al. 1999; Minder et al. 2007; Karrenberg and Favre 2008; Goulson 2009). This finding may prove to be quite general: in many systems, including in the Silene-Microbotryum system (Refrégier et al. 2008), closely related hosts are infected by closely related pathogens (as reviewed in de Vienne et al. 2013; see also Hafner et al. 1994; Jackson and Charleston 2004; Sorenson et al. 2004; Huyse and Volckaert 2005), making hybridization of both hosts and pathogens a possibility.

In several other fungal pathogen systems, hybridization and recombination have been associated with increased infectivity and/or elevated disease severity (e.g., Batrachochytrium dendrobatitis of amphibian chytridiomycosis, Ophiostoma species of Dutch elm disease; Brasier et al. 1999; Newcombe et al. 2000; Fraser et al. 2005; Brasier and Kirk 2010; Farrer et al. 2011; Goss et al. 2011; McKenzie and Peterson 2012; Schloegel et al. 2012; Stukenbrock et al. 2012). We see potential for a similar association of hybridization and infectivity in $\mathrm{Mi}$ crobotryum. If the frequency of sympatry and hybridization between $\mathrm{MvSl}$ and $\mathrm{MvSd}$ is indeed on the rise (Gladieux et al. 2011), increased infectivity of hybrid pathogens on pure-spe- cies hosts may limit host population growth, via sterilization, and even drive populations to greater local extinction rates (Antonovics 2004). In turn, increased local extinction of hosts with hybrid pathogens may contribute to the rarity of hybrid pathogens observed in nature (Gladieux et al. 2011). Finally, the elevated success of $F_{1}$ hybrid pathogens on pure-species hosts could facilitate gene flow between pure-species pathogens. Such introgression might increase the infectivity of purespecies pathogens and elevate the burden of disease, as has been seen in other systems (Stukenbrock and McDonald 2008). The results of our study and contemporary increases in hybridization between host and pathogen species suggest the Silene-Microbotryum system as a tractable, natural model in which to further investigate potential increases in pathogen infectivity and severity as a consequence of hybridization.

\section{Acknowledgments}

We thank the collectors listed in tables A1 and A2. We are grateful to L. Giraud, O. Jonot, L. Saunois, A. Dubois, and V. Herraudet for help in the greenhouse. A. K. Gibson acknowledges a grant from the Fulbright Program and La Commission Franco-Américaine. T. Giraud acknowledges the ANR grants 06-BLAN-0201 and 07-BDIV-003 and ERC GenomeFun 309403. M. E. Hood acknowledges support from National Science Foundation grants DEB-0747222 and 1115765 .

\section{Literature Cited}

Alexander HM, J Antonovics 1995 Spread of anther-smut disease (Ustilago violacea) and character correlations in a genetically variable experimental population of Silene alba. J Ecol 83:783-794.

Alexander HM, A Maltby 1990 Anther-smut infection of Silene alba caused by Ustilago violacea: factors determining fungal reproduction. Oecologia 84:249-253.

Antonovics J 2004 Long-term study of a plant-pathogen metapopulation. Pages 471-488 in I Hanski, O Gaggiotti, eds. Ecology, genetics, and evolution of metapopulations. Academic Press, San Diego, CA.

Antonovics J, M Hood, J Partain 2002 The ecology and genetics of a host shift: Microbotryum as a model system. Am Nat 160(suppl): S40-S53.

Arnold ML 2004 Natural hybridization and the evolution of domesticated, pest and disease organisms. Mol Ecol 13:997-1007.

Arnold ML, SA Hodges 1995 Are natural hybrids fit or unfit relative to their parents? Trends Ecol Evol 10:67-71.

Baker HG 1948 Stages in invasion and replacement demonstrated by species of Melandrium. J Ecol 36:96-119.

Biere A, J Antonovics 1996 Sex-specific costs of resistance to the fungal pathogen Ustilago violacea (Microbotryum violaceum) in Silene alba. Evolution 50:1098-1110.

Brasier CM 2001 Rapid evolution of introduced plant pathogens via interspecific hybridization. BioScience 51:123-133.

Brasier CM, D Cooke, J Duncan 1999 Origin of a new Phytophthora pathogen through interspecific hybridization. Proc Natl Acad Sci USA 96:5878-5883.

Brasier CM, SA Kirk 2010 Rapid emergence of hybrids between the two subspecies of Ophiostoma novo-ulmi with a high level of pathogenic fitness. Plant Pathol 59:186-199.
Brasier CM, S Kirk, N Pipe, K Buck 1998 Rare hybrids in natural populations of the Dutch elm disease pathogens Ophiostoma ulmi and O. novo-ulmi. Mycol Res 99:205-215.

Brown IH, PA Harris, JW McCauley, DJ Alexander 1998 Multiple genetic reassortment of avian and human influenza A viruses in European pigs, resulting in the emergence of an $\mathrm{H} 1 \mathrm{~N} 2$ virus of novel genotype. J Gen Virol 79:2947-2955.

Bucheli E, B Gautschi, J Shykoff 2001 Differences in population structure of the anther smut fungus Microbotryum violaceum on two closely related host species, Silene latifolia and S. dioica. Mol Ecol 10:285-294.

Büker B, E Petit, D Begerow, ME Hood 2013 Experimental hybridization and backcrossing reveal forces of reproductive isolation in Microbotryum. BMC Evol Biol 13:224.

Burke JM, ML Arnold 2001 Genetics and the fitness of hybrids. Annu Rev Genet 35:31-52.

Cafuir L, J Antonovics, ME Hood 2007 Tissue culture and quantification of individual-level resistance to anther-smut disease in Silene vulgaris. Int J Plant Sci 168:415-419.

Carius HJ, TJ Little, D Ebert 2001 Genetic variation in a host-parasite association: potential for coevolution and frequency-dependent selection. Evolution 55:1136-1145.

Carlsson-Granér U 1997 Anther-smut disease in Silene dioica: variation in susceptibility among genotypes and populations, and patterns of disease within populations. Evolution 51:1416-1426.

Delmotte F, E Bucheli, J Shykoff 1999 Host and parasite population structure in a natural plant-pathogen system. Heredity 82:300-308.

Denchev CM, T Giraud, ME Hood 2009 Three new species of anthericolous smut fungi on Caryophyllaceae. Mycol Balc 6:79-84. de Vienne DM, G Réfregier, ME Hood, A Guigue, B Devier, E Vercken, 
C Smadja, A Deseille, T Giraud 2009 Hybrid sterility and inviability in the parasitic fungal species complex Microbotryum. J Evol Biol 22:683-698.

de Vienne DM, G Refrégier, M López-Villavicencio, A Tellier, ME Hood, T Giraud 2013 Cospeciation vs host-shift speciation: methods for testing, evidence from natural associations and relation to coevolution. New Phytol 198:347-385.

Devier B, G Aguileta, ME Hood, T Giraud 2010 Using phylogenies of pheromone receptor genes in the Microbotryum violaceum species complex to investigate possible speciation by hybridization. Mycologia 102:689-696.

Dobzhansky T 1936 Studies on hybrid sterility. II. Localization of sterility factors in Drosophila pseudoobscura hybrids. Genetics 21: 113-135.

Farrer RA, LA Weinert, J Bielby, TWJ Garner, F Balloux, F Clare, J Bosch, et al 2011 Multiple emergences of genetically diverse amphibian-infecting chytrids include a globalized hypervirulent recombinant lineage. Proc Natl Acad Sci USA 108:18732-18736.

Fraser JA, SS Giles, EC Wenink, SG Guenes-Goyer, JR Wright, S Diezmann, A Allen, et al 2005 Same-sex mating and the origin of the Vancouver Island Cryptococcus gattii outbreak. Nature 437:13601364.

Fritz RS, C Moulia, G Newcombe 1999 Resistance of hybrid plants and animals to herbivores, pathogens, and parasites. Annu Rev Ecol Syst 30:565-591.

Gibson AK, ME Hood, T Giraud 2012 Sibling competition arena: selfing and a competition arena can combine to constitute a barrier to gene flow in sympatry. Evolution 66:1917-1930.

Giles BE, TM Pettersson, U Carlsson-Granér, PK Ingvarsson 2006 Natural selection on floral traits of female Silene dioica by a sexually transmitted disease. New Phytol 169:729-739.

Giraud T 2004 Patterns of within population dispersal and mating of the fungus Microbotryum violaceum parasitising the plant Silene latifolia. Heredity 93:559-565.

Giraud T, P Gladieux, S Gavrilets 2010 Linking the emergence of fungal plant diseases with ecological speciation. Trends Ecol Evol 25:387-395.

Giraud T, S Gourbière 2012 The tempo and modes of evolution of reproductive isolation in fungi. Heredity 109:204-214.

Giraud T, G Refrégier, M Le Gac, DM de Vienne, ME Hood 2008 Speciation in fungi. Fungal Genet Biol 45:791-802.

Gladieux P, E Vercken, M Fontaine, ME Hood, O Jonot, A Couloux, T Giraud 2011 Maintenance of fungal pathogen species that are specialized to different hosts: allopatric divergence and introgression through secondary contact. Mol Biol Evol 28:459-471.

Goss EM, ME Cardenas, K Myers, GA Forbes, WE Fry, S Restrepo, NJ Grünwald 2011 The plant pathogen Phytophthora andina emerged via hybridization of an unknown Phytophthora species and the Irish potato famine pathogen, P. infestans. PLoS ONE 6:e24543.

Goulson D 2009 Evaluating the role of ecological isolation in maintaining the species boundary between Silene dioica and S. latifolia. Plant Ecol 205:201-211.

Goulson D, K Jerrim 1997 Maintenance of the species boundary between Silene dioica and S. latifolia (red and white campion). Oikos 79:115-126.

Gross BL, LH Rieseberg 2005 The ecological genetics of homoploid hybrid speciation. J Hered 96:241-252.

Hafner M, P Sudman, F Villablanca, T Spradling, J Demastes, S Nadler 1994 Disparate rates of molecular evolution in cospeciating hosts and parasites. Science 265:1087-1090.

Holmes EC, E Ghedin, N Miller, J Taylor, Y Bao, K St. George, BT Grenfell, et al 2005 Whole-genome analysis of human influenza A virus reveals multiple persistent lineages and reassortment among recent H3N2 viruses. PLoS Biol 3:e300.

Huyse T, FAM Volckaert 2005 Comparing host and parasite phylog- enies: Gyrodactylus flatworms jumping from goby to goby. Syst Biol 54:710-718.

Jackson AP, MA Charleston 2004 A cophylogenetic perspective of RNA virus evolution. Mol Biol Evol 21:45-57.

Kamoun S 2001 Nonhost resistance to Phytophthora: novel prospects for a classical problem. Curr Opin Plant Biol 4:295-300.

Karrenberg S, A Favre 2008 Genetic and ecological differentiation in the hybridizing campions Silene dioica and S. latifolia. Evolution 62:763-773.

Kemler M, M Goker, F Oberwinkler, D Begerow 2006 Implications of molecular characters for the phylogeny of the Microbotryaceae (Basidiomycota: Urediniomycetes). BMC Evol Biol 6:35.

Laine AL 2004 Resistance variation within and among host populations in a plant-pathogen metapopulation: implications for regional pathogen dynamics. J Ecol 92:990-1000.

Lam TT, J Wang, Y Shen, B Zhou, L Duan, CL Cheung, C Ma, et al 2013 The genesis and source of the H7N9 influenza viruses causing human infections in China. Nature 502:241-244.

Le Gac M, ME Hood, E Fournier, T Giraud 2007a Phylogenetic evidence of host-specific cryptic species in the anther smut fungus. Evolution 61:15-26.

Le Gac M, ME Hood, T Giraud 2007b Evolution of reproductive isolation within a parasitic fungal species complex. Evolution 61: 1781-1787.

Lewontin RC, LC Birch 1966 Hybridization as a source of variation for adaptation to new environments. Evolution 20:315-336.

Little TJ, CB Watt, D Ebert 2006 Parasite-host specificity: experimental studies on the basis of parasite adaptation. Evolution 60: 31-38.

Lively CM, MF Dybdahl, J Jokela, EE Osnas, LF Delph 2004 Host sex and local adaptation by parasites in a snail-trematode interaction. Am Nat 164(suppl):S6-S18.

Lutz M, M Platek, M Kemler, A Chlebicki, F Oberwinkler 2008 Anther smuts of Caryophyllaceae: molecular analyses reveal further new species. Mycol Res 112:1280-1296.

Mallet J 2007 Hybrid speciation. Nature 446:279-283.

McKenzie VJ, AC Peterson 2012 Pathogen pollution and the emergence of a deadly amphibian pathogen. Mol Ecol 21:5151-5154.

Minder A, C Rothenbuehler, A Widmer 2007 Genetic structure of hybrid zones between Silene latifolia and Silene dioica (Caryophyllaceae): evidence for introgressive hybridization. Mol Ecol 16:25042516.

Minder A, A Widmer 2008 A population genomic analysis of species boundaries: neutral processes, adaptive divergence and introgression between two hybridizing plant species. Mol Ecol 17:1552-1563.

Muller H 1942 Isolating mechanisms, evolution and temperature. Biol Symp 6:71-125.

Muller H, G Pontecorvo 1940 Recombinants between Drosophila species the $F_{1}$ hybrids of which are sterile. Nature 146:199-200.

Nelson MI, C Viboud, L Simonsen, RT Bennett, SB Griesemer, K St. George, J Taylor, et al 2008 Multiple reassortment events in the evolutionary history of H1N1 influenza A virus since 1918. PLoS Path 4:e1000012.

Newcombe G, B Stirling, S McDonald, HD Bradshaw 2000 Melampsora $\times$ columbiana, a natural hybrid of M. medusae and M. occidentalis. Mycol Res 104:261-274.

Olson A, J Stenlid 2002 Pathogenic fungal species hybrids infecting plants. Microbes Infect 4:1353-1359.

Oudemans PV, HM Alexander, J Antonovics, S Altizer, PH Thrall, L Rose 1998 The distribution of mating-type bias in natural populations of the anther-smut Ustilago violacea on Silene alba in Virginia. Mycologia 90:372-381.

Refrégier G, ME Hood, T Giraud 2010 No evidence of reproductive character displacement between two sister fungal species causing anther smut in Silene. Int J Plant Sci 171:847-859.

Refrégier G, M Le Gac, F Jabbour, A Widmer, ME Hood, T Gi- 
raud 2008 Cophylogeny of the anther smut fungi and their caryophyllaceous hosts: prevalence of host shifts and importance of delimiting parasite species. BMC Evol Biol 8:100.

Rieseberg LH 2003 Major ecological transitions in wild sunflowers facilitated by hybridization. Science 301:1211-1216.

Salvaudon L, V Heraudet, J Shykoff 2007 Genotype-specific interactions and the trade-off between host and parasite fitness. BMC Evol Biol 7:189.

Schäfer AM, M Kemler, R Bauer, D Begerow 2010 The illustrated life cycle of Microbotryum on the host plant Silene latifolia. Can J Bot 88:875-885.

Schloegel LM, LF Toledo, JE Longcore, SE Greenspan, CA Vieira, M Lee, S Zhao, et al 2012 Novel, panzootic and hybrid genotypes of amphibian chytridiomycosis associated with the bullfrog trade. Mol Ecol 21:5162-5177.

Sloan DB, T Giraud, ME Hood 2008 Maximized virulence in a sterilizing pathogen: the anther-smut fungus and its co-evolved hosts. J Evol Biol 21:1544-1554.

Sorenson MD, CN Balakrishnan, RB Payne 2004 Clade-limited colonization in brood parasitic finches (Vidua spp.). Syst Biol 53:140153.
Stukenbrock EH, FB Christiansen, TT Hansen, JY Dutheil, MH Schierup 2012 Fusion of two divergent fungal individuals led to the recent emergence of a unique widespread pathogen species. Proc Natl Acad Sci USA 109:10954-10959.

Stukenbrock EH, BA McDonald 2008 The origins of plant pathogens in agro-ecosystems. Annu Rev Phytopathol 46:75-100.

Thomas A, J Shykoff, O Jonot, T Giraud 2003 Sex-ratio bias in populations of the phytopathogenic fungus Microbotryum violaceum from several host species. Int J Plant Sci 164:641-647.

Thrall PH, AM Jarosz 1994 Host-pathogen dynamics in experimental populations of Silene alba and Ustilago violacea. I. Ecological and genetic determinants of disease spread. J Ecol 82:549-559.

Van Putten WF, A Biere, JMM Van Damme 2005 Host-related genetic differentiation in the anther smut fungus Microbotryum violaceum in sympatric, parapatric, and allopatric populations of two host species Silene latifolia and S. dioica. J Evol Biol 18:203-212.

Van Putten WF, JA Elzinga, A Biere 2007 Host fidelity of the pollinator guilds of Silene dioica and Silene latifolia: possible consequences for sympatric host race differentiation of a vectored plant disease. Int J Plant Sci 168:421-434. 